\title{
9 International Law and Extraterritorial Protection
}

IN THE SECOND PART of this work, we have sketched an overall image of the EU acquis related to extraterritorial protection and singled out a number of binding norms which seem to be on a collision course with universalist interests. Now we shall proceed to testing the viability of these norms under international law. To do so presupposes that we know which norms of international law have a bearing on access to territory, procedures and protection, and what their precise content is. To clarify these matters, and to establish benchmarks to test the acquis against, shall be the task of this chapter.

But before embarking on the black letter of law, let us recapitulate the legal environment in which flight and refuge is posited. A person leaves her country of origin and attempts to reach another country in quest of protection. This is the basic scenario of refugee law, and it involves three main entities: an individual, the country of origin and the potential host country. To be sure, the relationship between the individual and both states is characterised alienage. ${ }^{1024}$ Firstly, staying in the country of origin is not an option, due to the threats faced there. Secondly, the potential host state is not her country of nationality, which makes her presence on

1024 Hathaway has introduced this term when describing the relationship between a refugee and her country of origin, as expressed in the territorial requirement of Art. 1 A (2) of the 1951 Refugee Convention. See J. Hathaway, The Law of Refugee Status (1991, Butterworths, Toronto), p. 27.

(C) GREGOR NOLL, 2000 | DOI:10.1163/9789004461543_010

This is an open access chapter distributed under the terms of the CC BY-NC 4.0 license. 


\section{CHAPTER 9}

its territory contestable. Given this situation, it is of crucial interest how the issue of transition between the territories as well as the communities of both states is managed. In that sense, refugee law is certainly about movement ${ }^{1025}$-both in a physical and a social sense.

Possessing a defined territory and a permanent population are two preconditions for the international personality of a state. ${ }^{1026}$ These constitutive elements are simultaneously the objects of state power. As a corollary flowing from territorial and personal supremacy, states are entitled to control the composition of their population. The existence of this qualified ${ }^{1027}$ state right is unchallenged. Basically, this right is part of customary international law; it finds its expression in a large number of treaty instruments ${ }^{1028}$, in case law ${ }^{1029}$, and in doctrine ${ }^{1030}$. Within certain

1025 P. Tuitt, False Images. The Law's Construction of the Refugee (1996, Pluto Press, London), p. 6.

1026 Convention on the Rights and Duties of States, Montevideo, 26 December 1933, 165 LNTS 19, [not in force], Art. 1. To be considered a person of international law, a state must also possess a permanent population, a government and the capacity to enter into relations with other states. The quoted provision is generally regarded as reflecting customary international law.

1027 This right is qualified inter alia by the rules of asylum law and human rights law. By way of example, it is illegal to alter the composition of the state population by delivering refugees to their persecutors, by arbitrarily depriving persons of their nationality, or by committing genocide. Beyond such clear-cut cases, hard cases remain, where the precise delimitation of the state right to control the composition of its population has to be singled out.

1028 A corollary of this state right to control immigration is the qualified right to return nonnationals to their country of origins, which is regarded as part of customary law and has been codified as such in a large number of bi- and multilateral readmission agreements. See, e.g., the preamble of the 1992 German-Romanian readmission agreement, reaffirming the international obligation to readmit nationals. Vereinbarung zwischen dem Bundesminister des Innern der Bundesrepublik Deutschland und dem Innenministerium von Rumänien über die Rückübernahme von deutschen und rumänischen Staatsangehörigen, 1. November 1992, ILM vol. 31 (1992), pp. 1296-1300, BGBl. 1993 II, pp. 220-1.

1029 As early as in 1892, the U.S. Supreme Court affirmed that was 'an accepted maxim of international law, that every sovereign nation has the power, as inherent in sovereignty, and essential to its self-preservation, to forbid the entrance of foreigners within its dominions, or to admit them only in such cases and upon such conditions as it may see fit to prescribe'. U.S. Supreme Court, Nishimura Ekiu v. United States, 142 US 651, 659 (1892). In 1955, Judge Read formulated this right as follows in his dissenting opinion in Nottebohm: 'When an alien comes to the frontier, seeking admission, either as a settler or on a visit, the State has an unfettered right to refuse admission'. ICJ, Nottebobm Case, ICJ Reports 1955, p. 46. In the light of our discussion in this chapter, it is doubtful 
limits, a state is thus entitled to remove a non-national from its territory. As mentioned earlier, 'boundedness' is regarded as a precondition for forming protective communities within political theory. ${ }^{1031}$ Refugee law is a striking illustration of the mutual presupposition of protective community and boundary. For the ensuing analysis, it merits retaining that the boundary is twofold, featuring a geographical as well as a social dimension. The bounded community of a state is a function of territory and people. Both dimensions are legally controlled, and an analysis of refugee law will remain incomplete as long as one of them is omitted.

In law, the significance of a state's territorial and personal extension translates into the regulation of migration, which means controlling the physical movement of persons across state borders. To transgress the geographical boundary severing communities, a protection seeker has to leave her home country and gain access to a host country. ${ }^{1032}$ In turn, the social boundary translates into the regulation of extraterritorial protection. For even where the individual protection seeker has managed to migrate, the question of social inclusion remains. Either the individual is allowed to stay or physically sent back.

To do justice to the double boundary, our further inquiry into international law needs to be guided by two principal questions:

whether this right indeed is an unfettered one. - In its judgements concerning Art. 3 ECHR, the European Court of Human Rights has repeatedly spelt out that states are entitled to control the entry of aliens on their territory. See e.g., Nsona v. the Netherlands, ECHR Reports 1996-V, No. 22, at para. 92.

1030 R. Plender, International Migration Law (1988, Martinus Nijhoff Publishers, Dordrecht/Boston/London), p. 1, with further references to earlier doctrinal texts; The movement of persons across borders, L. B. Sohn and T. Buergenthal (eds), (1992, The American Society of International Law, Washington D.C.), p. 1; Verdross and Simma, 1984, p. 799.

1031 See text accompanying note 199 above.

1032 Migration is also relevant in the context of return. Taking the case where a protection seeker has been denied extraterritorial protection by a potential host state, the individual right to return may facilitate the exercise of the host state's right to control the composition of its population. This is the case when the protection seeker wishes to return, confronting the country of origin not only with the inter-state claim to readmission, but also with a human rights-based claim to readmission. See section 9.2.1 below. 


\section{CHAPTER 9}

1. Are EU Member States under an obligation to grant extraterritorial protection?

2. Are EU Member States under an obligation to let the individual migrate in order to seek such protection? ${ }^{1033}$

The first question, relating to the social boundary, will be pursued under the heading 'Protection' in the present and the subsequent chapter. The second question, relating to the geographical boundary, shall be dealt with in a corresponding manner under the heading 'Access'. There is a reason for ordering both questions in this manner. As we shall see, not all beneficiaries of protection obligations are beneficiaries of obligations to allow access to state territory. Thus, it makes sense to delimit the broader class of beneficiaries first, before identifying their legal options to gain access to state territory.

In a first step, we will identify such norms having a prima facie relevance for the issues raised in the two questions. The base thus established shall function as a common point of reference when answering the questions on the existence, coverage and nature of protective norms. Second, we shall identify the methodology of interpretation international law assigns us to use. The third step will be to apply this methodology of interpretation to the norms belonging to the normative base. Quite obviously, the goal shall be to determine the content of binding legal

${ }^{1033}$ The reader will note that the state is the subject of the two questions, and not the individual protection seeker. One might as well have asked 'Is there an individual entitlement to grant extraterritorial protection?' and 'Is there an individual entitlement to migrate in order to seek such protection?'. As formulating a question is to predetermine its answers, a certain bias could be suspected in that choice. Clearly, there is a bias attributable to international law. Even within the domain of human rights, the vast majority of norms in international law is of an inter-state character, and cannot be invoked directly by individuals. Therefore, an inquiry into state obligations will yield a larger number of norms than one seeking to identify corresponding individual entitlements. Conversely, an inquiry limited to individual entitlements will provide only a fragmentary picture of the array of norms impacting upon extraterritorial protection. Thus, it is reasonable to use the broader concept of state obligations as a point of departure. This choice is supported by the fact that the issue is of limited practical importance. First, even a universalist interpreter has a hard time arguing that the norms singled out in the normative base below are 'directly applicable' or 'self-executing'. Second, as relevant norms of international law are transformed into the domestic law of a number of Member States, there is little or no 'added value' in invoking them domestically. Third, the individual's access to monitoring bodies under the ECHR, ICCPR and CAT reduces the interest for direct applicability. 
norms, drawing on the positions taken by various actors of international law, treaty monitoring bodies, courts and doctrinal writers. However, as we shall see, this monolithic reading shall collapse at certain points, and two separate streams of legal reasoning will emerge. Those are the hard cases. By the end of this chapter, we will know which they are, and in the subsequent chapter, we shall try to dissolve the ambiguities haunting them.

\subsection{Protection}

Which norms of international law may have a bearing on a state's obligation to grant extraterritorial protection? This section starts out with inquiring into the normative quality of the UDHR, and continues with a survey of express and implicit prohibitions of refoulement in both human rights law and humanitarian law.

\subsubsection{A Right to Seek and Enjoy Asylum?}

In the quest for a common normative base, it is reasonable to revert to norms of a foundational character. In a double sense, the norms of the Universal Declaration of Human Rights fall within this category. Historically, they are foundational in that the UDHR was the first international human rights instrument of the post-war era. Considering their material content, they are foundational due to their level of abstraction. This allows an observer to regard the UDHR as an epicentre in the formation of the international system of human rights. Tracing these formative developments brings us to global and regional human rights treaties as well as to the 1951 Refugee Convention, all of which contain important extensions of the norms enshrined in the UDHR.

Article 14 UDHR is of prima facie relevance for the first question asked in this chapter. It is about transgressing the social boundary between home community and host community:

1. Everyone has the right to seek and to enjoy in other countries asylum from persecution. 


\section{CHAPTER 9}

2. This right may not be invoked in the case of prosecutions genuinely arising from non-political crimes or from acts contrary to the purposes and principles of the United Nations.

It should be noted that Article 14 is subject to the limitations in Article 29 and $30 \mathrm{UDHR}$.

To wit, there is no identically or similarly worded successor to Article 14 UDHR in treaty law with a universal scope. ${ }^{1034}$ The prohibitions of refoulement to be presented later in this chapter are all less sweepingly worded, and none makes allusion to the right to seek and to enjoy asylum. If this provision turned out to be binding, it might, at best, provide universalists with raw material to argue for a broader scope of protection than that available under the prohibitions of refoulement dealt with below. ${ }^{1035}$ This would probably not only be of importance for protection obligations, but also for obligations to allow access to the territory of potential host states. By way of example, Article 14 UDHR could play a role in countering the indiscriminate exclusion effectuated by pre-entry measures such as visa requirements and carrier sanctions. Given the singularity of the norm enshrined in Article 14 UDHR on the universal level and its potential for the universalist cause, it is reasonable to inquire into its character as binding international law. ${ }^{1036}$

1034 On a regional level, a right similar to Art. 14 UDHR can be found in Art. 22.7 of the American Convention on Human Rights ('Every person has the right to seek and be granted asylum in a foreign territory, in accordance with the legislation of the state and international conventions, in the event he is being pursued for political offences or related common crimes.') and Art. 12.3 of the African Charter on Human and Peoples Rights ('Every individual shall have the right, when persecuted, to seek and obtain asylum in other countries in accordance with the law of those countries and international conventions.').

${ }^{1035}$ However, such universalist arguments could be met with powerful particularist ones, claiming that the UDHR laid down a state obligation to respect the grant of asylum by other states. See, e.g., Å. Holmbäck, 'Förenta nationerna och asylrätten', in 1949 års utlänningskommitté, SOU 1951:42. Betänkande med förslag till Utlänningslag m.m. (1951, Stockholm), p. 292, arguing on the basis of the travaux. There would be no point in exploring the value of these arguments within the framework of our inquiry, if the UDHR turned out to be non-binding. Hence, the question of bindingness must be dealt with first.

${ }^{1036}$ For a detailed overview of the positions taken by different doctrinal writers, see P. R. Ghandhi, 'The Universal Declaration of Human Rights at Fifty Years', 41 GYIL 206 (1999), pp. 234-50. Ghandhi himself supports what we shall identify as the second position below, holding that certain provisions of the UDHR have acquired binding force as customary law. 
As the UDHR was drafted and adopted as a non-binding declaration, it is clear that the Article 14 UDHR does not possess compulsory force per se. Therefore it must be asked whether Article 14 has acquired binding force by any other means than incorporation into universal treaty law. Three positions offer themselves. The first holds that the UDHR as a whole is to be regarded as binding. The second holds that single rights contained in it possess binding force, and that Article $14 \mathrm{UDHR}$ is among them. If neither of these positions is tenable, we have to endorse a third one: the norms expressed in the named provisions do not oblige states in a legal sense.

Setting out with the first position, it has been claimed that the UDHR as a whole has acquired the quality of customary law. A broad range of evidence has been adduced in support of this position, spanning from the incorporation of human rights provisions in national constitutions ${ }^{1037}$ to state practice in the General Assembly ${ }^{1038}$ and elsewhere, to the dicta of various international and domestic courts. ${ }^{1039}$

However, to allow for the construction of custom, state practice needs to satisfy a requirement of uniformity. ${ }^{1040}$ The ways and means by which the rights of the UDHR are reflected in national constitutions vary to a considerable degree. By way of example, a right reminiscent of that enshrined in Article 14 UDHR can only be found in a handful of constitutions. ${ }^{1041}$ These rights usually turn on the right to obtain asylum, which is something quite different than the right to seek and to enjoy asylum. Furthermore, they are by no means sufficiently uniform in wording or in content. In addition, Schachter points out that actual state

${ }^{1037}$ For an enumeration with further references, see O. Schachter, International Law in Theory and Practice (1991, Martinus Nijhoff Publishers, Dordrecht/Boston/London), p. 336. Schachter himself doubts, however, that the whole content of the UDHR can be regarded as binding based on this evidence. He proposes a more selective approach, endowing single rights in the UDHR with the quality of customary international law. See Schachter, 1991, pp. 336-41.

1038 J. Humphrey, 'The Universal Declaration of Human Rights: Its History, Impact and Juridical Character', in B. G. Ramcharan (ed.), Human Rights Thirty Years After the Universal Declaration, Vol. II (1979, Martinus Nijhoff Publishers, The Hague), p. 29.

1039 See Schachter, 1991, p. 336 with further references.

1040 'State practice [...] should have been both extensive and virtually uniform in the sense of the provision invoked.' ICJ, North Sea Continental Shelf, p. 44, para. 74.

${ }^{1041}$ In the European context, Art. 16a (1) of the German Constitution and para. 4 of the Preamble to the French Constitution of 1946 provide pertinent examples of the right to asylum in national constitutions. 


\section{CHAPTER 9}

practice is not necessarily respectful of such constitutional rights. ${ }^{1042}$ Transposing Schachter's inquiry onto the level of statutory rights, we find ourselves faced with largely similar problems. Again, a number of domestic legislations contain a right to obtain asylum at the statutory level, but the scope and content of this right is not necessarily identical. ${ }^{1043}$ Therefore, the required uniformity in practice is missing in a twofold manner. This shortcoming also works against the argument that the UDHR is reflective of general principles of law in the sense of Article 38 (c) CICJ. ${ }^{1044}$ With regard to state practice in the General Assembly, Partsch has observed that 'a verbal reference to a non-binding instrument in later such instruments has no more effect than its first adoption'. ${ }^{1045}$ And the fact that courts have mentioned the UDHR in the same context as binding human rights instruments ${ }^{1046}$ does not reach much farther. Admittedly, one might apply the principle of ejusdem generis ${ }^{1047}$ when interpreting such quotes, and conclude that the court regards the UDHR to be normatively on an equal footing with the other instruments contained in the enumeration. However, it must be recalled that international law does not endow courts with the power to posit norms. ${ }^{1048}$ Therefore, quoting passages from court decisions is of little

${ }^{1042}$ Schachter, 1991, p. 336.

1043 The divergent interpretations of what constitutes 'persecution' in the sense of Art. 1 (A) (2) GC provide but one illustration of this fact. See text accompanying note 717 above.

1044 Carillo Salcedo maintains that the norms of the UDHR reflect such principles and consequently must be regarded as binding. J. Carrillo Salcedo, 'Human Rights, Universal Declaration of (1948)', in R. Bernhardt (ed.), Encyclopedia of Public International Law (1999, North Holland, Amsterdam), p. 303.

${ }^{1045}$ K. J. Partsch, 'Article 55 (c)', in B. Simma (ed.), The Charter of the United Nations. A Commentary (1994, OUP, Oxford), p. 783.

1046 See e.g. the following passage from the Tehran Hostage Case: 'Wrongfully to deprive human beings of their freedom and to subject them to physical constraint in conditions of hardship is manifestly incompatible with the principles of the Charter of the United Nations as well as with the fundamental principles enunciated in the Universal Declaration of Human Rights'. Case concerning United States Diplomatic and Consular Staff in Tebran, I.C.J. Rep., 1980, 3 at 42.

1047 'In the construction of laws, wills, and other instruments, the "ejusdem generis rule" is, that where general words follow an enumeration of persons or things, by words of a particular and specific meaning, such general words are not to be construed in their widest extent, but are to be held as applying only to persons or things of the same general kind or class as those specifically mentioned.' H. C. Black, Black's Law Dictionary (1979, West Publishing Company, St. Paul), p. 464.

1048 This is clear from Art. 38 SICJ. 
help, as long as they fail to produce convincing material arguments for the binding nature of the UDHR.

Taking a different approach, the UDHR may be regarded as an authoritative specification of the obligation to respect and observe human rights contained in Article 55 (c) UNC. ${ }^{1049}$ As the Member States have pledged in Article 56 UNC to take joint and separate action in cooperation with the UN for the achievement of the purposes set out in Article 55, one might argue that this pledge would cover the catalogue of rights set out in the UDHR. The UDHR as such would remain nonbinding, but its content would be binding upon UN Member States according to the terms of the UNC. However, this position has been met with strong counter-arguments. The purpose of promoting universal respect for human rights enunciated in Article 55 (c) UNC is too unspecified to qualify as a legal norm and should rather be regarded as a programme for further action. The sole exception would be the prohibition of discrimination integrated in that provision, which is regarded as a binding legal norm. ${ }^{1050}$ However, non-discrimination is not at stake here. Moreover, to be convincing, the linkage between the UDHR and Article 55 (c) must find support in state practice. On the level of single states, this brings us back to the problem of the lack of uniformity expounded in the preceding paragraph. On the level of the United Nations Economic and Social Council, such practice only covers gross and systematic violations of human rights. Therefore, the normative content of the UDHR as a whole boils down to a prohibition of gross and systematic violations of human rights in general international law. ${ }^{1051}$ Given the high level of abstraction as well as the considerable threshold inherent in the terms 'gross' and 'systematic', this norm has no direct import on our questions.

With regard to the second position, it would be necessary to embark on an assessment of the normative quality of Article $14 \mathrm{UDHR}$. On the

1049 For a similar, albeit less specified approach, see L. B. Sohn, 'The New International Law: Protection of the Rights of Individuals rather than States', 32 Am.U.L.Rev 16 (1982), and Carrillo Salcedo, 1999, p. 303.

1050 K. J. Partsch, 'Human Rights in General', in R. Wolfrum (ed.), United Nations: Lawe, Policies and Practice (1995, Martinus Nijhoff Publishers, Dordrecht/London/Boston), p. 606, mn 14, referring to Advisory Opinion on Namibia, ICJ Reports 1971, 16 (57).

1051 Partsch, 1995, p. 609, mn 30. For an account on the practice in ECOSOC, see K. J. Partsch, 'Article 68', in B. Simma (ed.), The Charter of the United Nations. A Commentary (1994, OUP, Oxford), pp. 890-2. 


\section{CHAPTER 9}

understanding that Article $14 \mathrm{UDHR}$ is something else than just a positive formulation of Article $33 \mathrm{GC}^{1052}$ and exceeds the normative content of the latter, there is no basis for such a finding. Neither a homogeneous state practice nor a corresponding opinio juris can be made out. This explains why the terms of Article 14 UDHR are missing in the list of customary human rights norms that doctrinal writers have compiled. ${ }^{1053}$

To conclude, it has become clear that neither the UDHR generally, nor the specific content of Article 14 UDHR possess the quality of binding international law. ${ }^{1054}$ In keeping with the methodology outlined in the first chapter of this work, we shall focus on binding norms. Therefore, Article 14 UDHR must be excluded from the normative base uncierlying this work.

\subsubsection{Express Prohibitions of Refoulement in Human Rights Law}

\subsubsection{The 1951 Refugee Convention}

Undisputedly, the prohibition of refoulement is the centrepiece of international refugee law. Its most important manifestation is the wording of Article 33 of the 1951 Refugee Convention ${ }^{1055}$, binding not only upon the State Parties to that instrument, but also to those who have ratified the 1967 New York Protocol. ${ }^{1056}$ Article 33 GC is phrased as follows:

\footnotetext{
1052 See chapter 9.1.2.1 below.

1053 See inter alia American Law Institute, Restatement (Third) of the Foreign Relations Law of the United States, 1987, para 702. For a discussion of the 'listing' of customary human rights norms, see Schachter, 1991, pp. 338-42.

1054 This does not deprive the UDHR of its possible relevance for the interpretation of binding norms.

1055 Convention relating to the Status of Refugees, 28 July 1951, 189 UNTS 137.

1056 See Art. 1 (1) of the New York Protocol: 'The States Parties to the present Protocol undertake to apply Articles 2 to 34 inclusive of the Convention [on the Status of Refugees, GN] to refugees as hereinafter defined'. A provision similar to Art. 33 GC is contained in Art. 10 of the Agreement on Refugee Seamen. 'No refugee seaman shall be forced, as far as it is in the power of the Contracting Parties, to stay on board a ship which is bound for a port, or is due to sail through waters, where he has well-founded fear of persecution for reasons of race, religion, nationality, membership of a particular social group or political opinion.' The agreement does not contain an equivalent to Article 33 (2) GC.
} 


\section{EXTRATERRITORIAL PROTECTION}

1. No Contracting State shall expel or return ("refouler") a refugee in any manner whatsoever to the frontiers of territories where his life or freedom would be threatened on account of his race, religion, nationality, membership of a particular social group or political opinion.

2. The benefit of the present provision may not, however, be claimed by a refugee whom there are reasonable grounds for regarding as a danger to the security of the country in which he is, or who, having been convicted by a final judgment of a particularly serious crime, constitutes a danger to the community of that country.

It is clear, though, that the prohibition is not an absolute one. Paragraph 2 of Article 33 GC singles out a group of persons to which the benefit of non-refoulement is denied, even though they live up to the requirements set out in the refugee definition in Article 1 (A) (2) GC and are not excluded under Article 1 (F) GC. The wording of this paragraph is vague in a threefold manner. It is by no means clear when a person is to be regarded as a 'danger to the security' or a 'danger to the community' of a potential host country. The phrases 'reasonable grounds' and 'particularly serious crimes' beg further questions. Moreover, it is not quite clear which cases Article 33 (2) GC covers beyond the scope of Article 1 (F) GC.

It should be noted that the 1957 Agreement relating to Refugee Seamen ${ }^{1057}$ and the 1967 Protocol relating to the Status of Refugees ${ }^{1058}$ also feature a prohibition of refoulement. The pivotal importance of the prohibition of refoulement has been regularly reaffirmed by the General Assembly and by the UNHCR Executive Committee. Claims have been made that the prohibition of refoulement is also a part of customary international law. ${ }^{1059}$ Given the geographical scope of this work and that

\footnotetext{
1057 Agreement relating to Refugee Seamen of 23 November 1957, 506 UNTS 125.

1058 Protocol relating to the Status of Refugees, 31 January 1967, 606 UNTS 267.

1059 Affirming that the prohibition of refoulement is a norm of customary international law: Goodwin-Gill, 1996, p 167, Plender, 1988, p. 431, T. Meron, Human Rights and Humanitarian Norms as Customary Law (1989, Clarendon Press, Oxford), pp. 22-3. Denying that the prohibition of refoulement is a norm of customary international law: A. Grahl Madsen, The Status of Refugees in International Law, Vol. II (1972, A.W. Sijthoff, Leiden), p. 98, W. Kälin, Das Prinzip des Non-Refoulement. Das Verbot der Zurückweisung, Asuweisung und Auslieferung von Flüchtlingen in den Verfolgerstaat im Völkerrecht und im schweizerischen Landesrecht (1982, Peter Lang, Bern), p. 72, For further references, see H. Maaßen, Die Rechtsstellung des Asylbewerbers im Völkerrecht (1997, Peter Lang, Frankfurt
} 


\section{CHAPTER 9}

all Member States of the EU are parties to the GC, there is no need to pursue this question further. In the present context, a reference to the prohibition of refoulement relates to its manifestation in treaty law.

The 1951 Refugee Convention and the 1967 New York Protocol are binding upon all states of the European Union as well as upon all the first wave of candidate countries. They are regarded as part of the acquis communautaire. ${ }^{1060}$ Article 63 (1) TEC expressly prescribes that measures on asylum adopted by the Council must be in accordance with these instruments.

\subsubsection{The 1984 CAT}

Until recently, the discussion on extraterritorial protection had focused to a very large degree on the 1951 Refugee Convention. Still, the protective capacities of international law are not exhausted with that instrument. Apart from the instruments dedicated to refugee law named in the preceding section, a prohibition of refoulement is also represented in a human rights treaty of a more general portée. The 1984 Convention against Torture and Other Cruel, Inhuman or Degrading Treatment or Punishment ${ }^{1061}$ limits the right of states to remove aliens in Article $3^{1062}$ :

No State Party shall expel, return ("refouler") or extradite a person to another State where there are substantial grounds for believing that he would be in danger of being subjected to torture.

Generally, the CAT outlaws torture as well as cruel, inhuman or degrading treatment or punishment. The scope of the removal provision

am Main), p. 192 note 622.

1060 Draft List, para. I. A. b.

1061 Convention against Torture and Other Cruel, Inhuman or Degrading Treatment or Punishment, 10 December 1984, 1465 UNTS 85.

${ }^{1062}$ For an excellent overview of the case law related to Art. 3 CAT, see B. Gorlick, 'The Convention and the Committee against Torture: A Complementary Protection Regime for Refugees', 11 IJRL 3 (1999). Generally on Article 3 CAT: D. Weissbrodt and I. Hörtreiter, 'The Principle of Non-Refoulement: Article 3 of the Convention Against Torture and Other Cruel, Inhuman or Degrading Treatment or Punishment in Comparison with the Non-Refoulement Provisions of Other International Human Rights Treaties', 5 Buffalo Human Rights Law Review (1999). 
in Article 3, however, is limited to torture only. Given the fundamental character of the prohibition of torture, the CAT does not provide for derogation in states of exception. Therefore, the prohibition of removal to torture has been termed as absolute. ${ }^{1063}$ Hence, the CAT is drafted in a more inclusive manner than the 1951 Refugee Convention. ${ }^{1064}$

Through a declaration under Article 22 CAT, State Parties can choose to recognise the competence of the CAT Committee 'to receive and consider communications from or on behalf of individuals subject to its jurisdiction who claim to be victims of a violation by a State Party of the provisions of the Convention'. However, the decisions of the Committee merely possess the character of recommendations. ${ }^{1065}$ As it stands today, a significant portion of the cases considered by the Committee revolve around the issue of extraterritorial protection under Article $3 \mathrm{CAT}$.

Considering the number of ratifications by EU Member States and first wave candidate countries, the CAT has been well received. ${ }^{1066}$ It is in force for all states of both groupings, save for Belgium and Ireland. ${ }^{1067}$ The competence of the CAT Committee to receive individual complaints has been recognised by 11 of the remaining 13 EU Member States (Germany and the U.K. have refrained from doing so). Among first wave candidate countries, only Estonia has chosen not to endow the CAT Committee with that competence. Finally, it should be noted that the CAT is not on the list of instruments considered to form part of the acquis.

${ }^{1063}$ See, e.g., Weissbrodt and Hörtreiter, 1999, p. 16; J. Suntinger, 'The Principle of NonRefoulement: Looking Rather to Geneva than to Strasbourg?', 49 Austrian Journal of Public and International Law (1995), p. 208; and T. Harr ${ }^{1}$ Das völkerrechtliche Refoulementverbot abseits der Genfer Flüchtlingskonvention (1999, Peter Lang, Frankfurt am Main), p. 182, with further references in note 822.

1064 As earlier noted, Art. 33 (2) GC excludes certain groups from the benefit of Art. 33 (1) GC.

1065 Art. 22 CAT, para. 7.

1066 Information on ratification and acceptance of monitoring competence has been gathered from the following document: Status of Ratification As of 12 April 1999, UN Doc. No. A/MISC/99 (Chairpersons Meeting), 12.04.1999.

${ }_{1067}$ Both countries have signed, but not yet ratified CAT. 


\section{CHAPTER 9}

\subsubsection{Other Express Prohibitions of Refoulement in Human Rights Law?}

Article 5 of the 1977 European Convention on the Suppression of Terrorism ${ }^{1068}$ has also been qualified as a prohibition of refoulement. ${ }^{1069}$ The article reads as follows:

Nothing in this Convention shall be interpreted as imposing an obligation to extradite if the requested State has substantial grounds for believing that the request for extradition for an offence mentioned in Article 1 or 2 has been made for the purpose of prosecuting or punishing a person on account of his race, religion, nationality or political opinion, or that that person's position may be prejudiced for any of these reasons.

This clause represents a corollary of the prohibition of refoulement in Article 33 GC. ${ }^{1070}$ It exempts a certain category of persons from any extradition obligation under the Convention. Article 5 does not entitle an individual, nor does it prohibit a state, to carry out extradition in the named cases. It simply obliges a state requesting extradition to accept a denial by the requested state, because the extradition request is made for persecution-related reasons. Therefore, the quoted provision is unrelated to the two basic questions this chapter deals with.

\subsubsection{Express Prohibitions of Refoulement in Humanitarian Law}

Humanitarian law has hitherto played a subordinate role in the analysis of state obligations towards protection seekers. ${ }^{1071}$ An overtly rigid separation of refugee law, human rights law and humanitarian law may

\footnotetext{
1068 European Convention on the Suppression of Terrorism, 27 January 1977, ETS No. 90.

${ }^{1069}$ Hartl, 1999, p. 193.

${ }^{1070}$ However, it should be noted that the persecutory ground of 'membership of a particular social group' is absent in the quoted provision.

${ }^{1071}$ In this context, one should, however, take note of Melander's proposal to structure extraterritorial protection into two areas, one based on human rights law, and the other on humanitarian law. G. Melander, The Two Refugee Definitions (1987, Raoul Wallenberg Institute, Lund).
} 
underlie such neglect. ${ }^{1072}$ Given the existence of an explicit prohibition of refoulement in one of the basic instruments of contemporary humanitarian law, this attitude should be reconsidered.

Article 45 of the 1949 Geneva Convention Relative to the Protection of Civilian Persons in Time of War ${ }^{1073}$ states inter alia that

In no circumstances shall a protected person be transferred to a country where he or she may have reason to fear persecution for his or her political opinions or religious beliefs.

The provisions of this Article do not constitute an obstacle to the extradition, in pursuance of extradition treaties concluded before the outbreak of hostilities, of protected persons accused of offences against ordinary criminal law.

However, this prohibition of refoulement is both narrower and wider than its successor in the 1951 Refugee Convention. It merely covers the grounds of political opinion and religious beliefs, which is less than the five grounds enumerated in Article 33 of the latter instrument. By contrast, the phrase 'may have reason to fear' seems to set a lower threshold than 'well founded fear' in the refugee definition. Notably, the prohibition of refoulement in the Fourth Convention does not introduce any exclusion or cessation clauses and has been termed as absolute. ${ }^{1074}$

It must be underscored, though, that the general provisions of the Fourth Convention set out a rather narrow framework for the application of its Article 45. According to Article $2 \mathrm{FC}$, this Convention is applicable in any armed conflict between two or more contracting parties. Article 4 FC stipulates that 'Persons protected by the Convention are those who, at a given moment and in any manner whatsoever, find themselves, in case of a conflict or occupation, in the hands of a Party to the conflict or Occupying Power of which they are not nationals'. However, the same provision introduces further limitations, inter alia to the effect that nationals of a state not bound by the Convention are not protected by it. As long as their state of nationality has ratified the Convention, protection seekers may benefit from the provisions of the Convention. A

1072 For an analysis of the interrelationship between the three areas of law, see Melander, 1997.

1073 Convention Relative to the Protection of Civilian Persons in Time of War, 12 August 1949, 75 UNTS 287 [henceforth Fourth Convention, abbreviated FC].

1074 Pictet, 1958, p. 269. 


\section{CHAPTER 9}

temporal limitation is also to be taken into account: following Article 6 FC, the Convention applies from the outset of conflict until the general close of military operations. However, the final sentence of this article provides that '[p]rotected persons whose release, repatriation or reestablishment may take place after such dates shall meanwhile continue to benefit by the present Convention'.

The Kosovo conflict provides an example of how such an instrument as this might become relevant. The NATO intervention made a number of EU Member States and first wave candidate countries parties to an international armed conflict with the Federal Republic of Yugoslavia. All of the states were bound by the Fourth Convention. ${ }^{1075}$ A number of EU Member States and first wave candidate countries were confronted with protection claims from persons fleeing Kosovo. Apart from the explicit and implicit prohibitions of refoulement named elsewhere in this chapter, Article 45 FC may provide an additional safeguard against return. Given the very low recognition rate for Convention refugees from the Federal Republic of Yugoslavia in Germany ${ }^{1076}$, clarifying the impact of such an obligation would be a worthy task. The general interest of this question is not diminished by the fact that return to the Federal Republic of Yugoslavia was practically impossible during the conflict, as flights were banned by the UN embargo. This example goes to show that the applicability of the Fourth Convention presupposes that the Member State in which protection is sought is concurrently a party to an armed conflict falling under the Fourth Convention.

The Fourth Convention has been ratified by all Member States as well as all first wave candidate countries. ${ }^{1077}$ Given that its thematic centre of gravity is not Justice and Home Affairs, this instrument is not part of the acquis.

1075 Source: IHL Database, available at < http://www.icrc.org/ihl > (accessed on 24 April 0).

1076 In 1998, the Convention Recognition Rate for Germany amounted to a mere 4.2 percent. Source: UNHCR, Asylum Seekers and Refugees in Europe in 1998: A Statistical Assessment With A Special Emphasis on Kosovo Albanians (March 1999, UNHCR, Geneva), p. 15.

1077 Source: IHL Database, available at <http://www.icrc.org/ihl > (accessed on 24 April 0)). 


\subsubsection{Implicit Prohibitions of Refoulement in Treaty Law}

Apart from the comparatively straightforward prohibitions of refoulement spelt out word for word in treaty provisions, the observer is confronted with a number of norms that have been construed to imply a prohibition of refoulement. The basic assumption underlying such implied prohibitions of refoulement is that states are responsible for violations of human rights or humanitarian law by other actors to the extent their own action or omissions contribute to such violations. What constitutes a violation must be assessed against the background of international law obligations of the returning state.

\subsubsection{Human Rights Law}

With Article 33 GC and Article 3 CAT, international law possesses two treaty provisions prohibiting the refoulement of different groups of beneficiaries. Differently from the 1951 Refugee Convention and the CAT, the International Covenant of Civil and Political Rights of $1966^{1078}$ and the European Convention for the Protection of Human Rights and Fundamental Freedoms of $1950^{1079}$ do not contain explicit prohibitions of refoulement. However, some of the rights guaranteed by them have been construed by their treaty-monitoring bodies to protect from removal to a state where a claimant would be exposed to certain violations. In particular, norms prohibiting torture and other forms of ill-treatment have provided the base for barring removal. ${ }^{1080}$ In other words, such norms may contain an implicit prohibition of refoulement. This prohibition could, in turn, constitute a state obligation to grant extraterritorial protection.

For the purposes of this chapter, it is sufficient to scrutinise such an interpretation is tenable. As practice is most developed with regard to the prohibition of torture and other forms of ill-treatment, we shall limit our scrutiny to these norms. In cases brought before treaty monitoring bodies,

1078 International Covenant on Civil and Political Rights, 16 December 1966, 999 UNTS 171.

1079 European Convention for the Protection of Human Rights and Fundamental Freedoms, 4 November 1950, ETS No. 5.

1080 With regard to the ECHR, even other human rights guaranteed by it have been invoked in a manner reminiscent of non-refoulement arguments. See chapter 11.1 below. 


\section{CHAPTER 9}

torture and other forms of ill-treatment have been most frequently invoked as a basis for obtaining such protection. This in no way prejudices that other human rights imply entitlement to extraterritorial protection as well. What is at stake here, however, is whether extraterritorial protection can be justified under any of the rights guaranteed in the ECHR and the ICCPR. If such a justification is within reach, it may be asked exactly where the limits of extraterritorial protection under these instruments are. We shall revert to that question in a later chapter. ${ }^{1081}$

The prohibition of torture and other forms of ill-treatment has been codified on an universal level in Article 7 ICCPR, stating that

[n]o one shall be subjected to torture or to cruel, inhuman or degrading treatment or punishment. ${ }^{1082}$

This provision leaves no room for exceptions or limitations. Even in states of emergency, no derogation may be made from Article 7 ICCPR according to Article 4 (2) ICCPR.

All EU Member States and first wave candidate countries are bound by the ICCPR. ${ }^{1083}$ By ratifying the First Optional Protocol ${ }^{1084}$, State Parties to the ICCPR recognise the competence of the Human Rights Committee to receive and process individual complaints regarding the rights set out in the ICCPR. ${ }^{1085}$ In contradistinction to the judgements of the European Court of Human Rights, the decisions of the Human Rights Committee are not binding upon states. ${ }^{1086}$ The First Optional Protocol has been ratified by all states within the two groups save for the United Kingdom. ${ }^{1087}$ The ICCPR has not been included in the list of conventions forming part of the acquis.

\footnotetext{
1081 See chapter 11 below.

1082 Art. 5 UDHR is the identically worded historical predecessor of this norm.

1083 Information on ratification and acceptance of monitoring competence has been gathered from the following document: Status of Ratification As of 12 April 1999, UN Doc. No. A/MISC/99 (Chairpersons Meeting), 12.04.1999.

${ }^{1084}$ First Optional Protocol to the International Covenant on Civil and Political Rights, 19 December 1966, 999 UNTS 302 [henceforth First Optional Protocol], Art. 1.

1085 Art. 1 First Optional Protocol.

1086 Art. 5 (4) First Optional Protocol.

${ }^{1087}$ Information on ratification and acceptance of monitoring competence has been gathered from the following document: Status of Ratification As of 12 April 1999, UN Doc. No. A/MISC/99 (Chairpersons Meeting), 12.04.1999.
} 
Omitting the word 'cruel' contained in Article 7 ICCPR, Article 3 ECHR states that

[n]o one shall be subjected to torture or to inhuman or degrading treatment or punishment.

Article 3 ECHR makes no provision for exceptions. Furthermore, Article 15 (2) ECHR states that no derogation from this norm in time of war or other public emergency is permitted, which has brought some commentators to qualify the protection under Article $3 \mathrm{ECHR}$ as absolute. ${ }^{1088}$ Accordingly, it would be misplaced to weigh the interest of an applicant against the public interest in removal cases under Article 3 ECHR. ${ }^{1089}$

All Member States of the European Union and all Candidate Countries are bound by the ECHR. This instrument forms part of the acquis communautaire ${ }^{1090}$, and Article 6 (2) TEU provides that 'the Union shall

1088 A comprehensive discussion on the absolute character of Art. 3 and the inherent prohibition of refoulement can be found with Hartl, 1999, pp. 96-103; and R. Alleweldt, Schutz vor Abschiebung bei drobender Folter oder unmenschlicher oder erniedrigender Behandlung oder Strafe: Refoulement-Verbote im Völkerrecht und im deutschen Recht unter besonderer Berücksichtigung von Artikel 3 der Europäischen Menschenrechtskonvention und Artikel 1 des Grundgesetzes (1996, Springer, Berlin), p. $56 \mathrm{ff}$. Doubts on the adequacy of terming protection as 'absolute' have been raised by M. K. Addo and N. Grief, 'Does Article 3 of the European Convention on Human Rights Enshrine Absolute Rights?', 9 EJIL 3 (1998). See also the ambitious argumentation in S. Zühlke and J-C Pastille, 'Extradition and the European Convention-Soering Revisited', 59 ZaöRV 3 (1999), pp. 759-66, questioning to what extent 'absoluteness' is a helpful 'concept when scrutinising the effects of rights enshrined in Section I ECHR and denying that the absolute nature of a right is an indicator of superiority.

1089 Accord: N. Mole, 'Problems Raised by Certain Aspects of the Present Situation of Refugees from the Standpoint of the European Convention on Human Rights', in UNHCR, The European Convention on Human Rights and the Protection of Refugees, Asylum-Seekers and Displaced Persons (1996, UNHCR, Geneva), p. 40, analysing inter alia the Commission Report in the Chabal case. However, a weighing of public interests against the applicant's interests is precisely what a number of dissenting opinions in ECtHR cases propose: ECtHR, Vilvarajab and Others vs. the U.K., 30 November 1991, Series A 215 [henceforth Vilvarajah], Dissenting opinion of Judge Russo; and ECtHR, Chabal vs. the U.K., 15 November 1996, Reports 1996-V [henceforth Chahal], Joint Partly Dissenting Opinon of Judges Gölcüklü, Matscher, Freeland, Baka, Totchev, Bonnici and Levits. See also Hartl, 1999, p. 102, suggesting that there should be no weighing of interests, while pointing out that the public interest may impact the interpretation of the concept 'inhuman and degrading treatment'.

1090 Draft List, para. XII. A. b. 


\section{CHAPTER 9}

respect fundamental rights, as guaranteed by the European Convention for the Protection of Human Rights and Fundamental Freedoms signed in Rome on 4 November 1950 and as they result from the constitutional traditions common to the Member States, as general principles of Community law'.

A special feature of the ECHR is its powerful monitoring mechanism. Earlier, State Parties to the ECHR could choose to endow the Court with the competence to receive individual applications by making a declaration to that effect. After the restructuring of the Convention's control machinery through Protocol No. $11^{1091}$, acceptance of that competence has become an integral and mandatory part of the Convention. ${ }^{1092}$ Finally, State Parties have taken upon themselves an obligation to follow the judgements issued by the European Court of Human Rights. ${ }^{1093}$ As we shall see, the European monitoring bodies have played a critical role in developing the inherent prohibition of refoulement in human rights norms.

\subsubsection{Humanitarian Law}

Are there any implicit prohibitions of refoulement in humanitarian law? Marx has suggested that Article 3 common to the 1949 Geneva Conventions creates 'an immediate prohibition of refoulement for victims of civil war' ${ }^{1094}$ over and above its obligations to the parties to the conflict. His argument draws on the 1986 ICJ Decision in the Nicaragua case, where the Court had to pronounce itself on the question whether the

1091 Protocol No. 11 to the Convention for the Protection of Human Rights and Fundamental Freedoms, Restructuring the Control Machinery Established Thereby, 11 May 1994, ETS No. 155.

1092 See Art. 34 of the $11^{\text {th }}$ Protocol: 'The Court may receive applications from any person, non-governmental organisation or group of individuals claiming to be the victim of a violation by one of the High Contracting Parties set forth in the Convention or in the protocols thereto. The High Contracting Parties undertake not to hinder in any way the effective exercise of this right'.

1093 Art. 46 of the $11^{\text {th }}$ Protocol.

1094 R. Marx, 'Völkervertragsrechtliche Abschiebungshindernisse für Flüchtlinge', in K. Barwig (ed.), Ausweisung im demokratischen Rechtsstaat (1996, Nomos, Baden-Baden), at 299. Accord: M. Kjærum, 'Article 14', in G. Alfredsson and A. Eide (eds), The Universal Declaration of Human Rights. A Common Standard of Achievement (1999, Martinus Nijhoff Publishers, The Hague), p. 285. 
United States had violated humanitarian law by publishing a manual on guerrilla warfare and spreading it to the insurgent 'Contras' forces. ${ }^{1095}$

The cornerstone of this argumentation is the content of a provision included in each of the four 1949 Geneva Conventions ${ }^{1096}$, identically worded, allotted the same article number and therefore known as Common Article 3. This norm spells out basic protective obligations of State Parties bound by any of the four 1949 Geneva Conventions in situations of non-international armed conflicts:

In the case of armed conflict not of an international character occurring in the territory of one of the High Contracting Parties, each Party to the conflict shall be bound to apply, as a minimum, the following provisions:

(1) Persons taking no active part in the hostilities, including members of armed forces who have laid down their arms and those placed ' hors de combat ' by sickness, wounds, detention, or any other cause, shall in all circumstances be treated humanely, without any adverse distinction founded on race, colour, religion or faith, sex, birth or wealth, or any other similar criteria. To this end, the following acts are and shall remain prohibited at any time and in any place whatsoever with respect to the abovementioned persons:

(a) violence to life and person, in particular murder of all kinds, mutilation, cruel treatment and torture;

(b) taking of hostages;

(c) outrages upon personal dignity, in particular humiliating and degrading treatment;

(d) the passing of sentences and the carrying out of executions without previous judgment pronounced by a regularly constituted court, affording all the judicial guarantees which are recognized as indispensable by civilized peoples.

1095 Military and Paramilitary Activities in and against Nicaragua (Nicaragua v. United States of America), Merits, Judgment, ICJ Reports 1986, p. 14 [hereinafter Nicaragua Case].

1096 Convention (I) for the Amelioration of the Condition of the Wounded and Sick in Armed Forces in the Field, Geneva, 12 August 1949, 75 UNTS 31; Convention (II) for the Amelioration of the Condition of Wounded, Sick and Shipwrecked Members of Armed Forces at Sea, Geneva, 12 August 1949, 75 UNTS 85; Convention (III) relative to the Treatment of Prisoners of War, Geneva, 12 August 194975 UNTS 135; Convention (IV) relative to the Protection of Civilian Persons in Time of War, Geneva, 12 August 1949, 75 UNTS 287 [henceforth the 1949 Geneva Conventions]. 


\section{CHAPTER 9}

(2) The wounded and sick shall be collected and cared for. An impartial humanitarian body, such as the International Committee of the Red Cross, may offer its services to the Parties to the conflict. The Parties to the conflict should further endeavour to bring into force, by means of special agreements, all or part of the other provisions of the present Convention. The application of the preceding provisions shall not affect the legal status of the Parties to the conflict.

Due to a reservation by the United States that excluded multilateral treaties from the jurisdiction of the ICJ, the Court was prevented from considering the responsibility of the United States under themultilateral-1949 Geneva Conventions. Instead, it had to resort to a general principle of humanitarian law, consuming the content of Common Article 3, to pronounce itself on this matter. In the next step, it considered Common Article 3 to be an 'elementary standard of humanity' and, due to its minimum character, applicable in non-international and international conflicts alike. Further, the Court considered the United States to be party to an international conflict with Nicaragua, which would make the general principle of humanitarian law related to earlier applicable. ${ }^{1097}$

Subsequently, the Court found by fourteen votes to one that, under general principles of humanitarian law, the United States was bound to refrain from encouragement of persons or groups engaged in the conflict in Nicaragua to commit violations of common Article 3 of the four Geneva Conventions of 12 August 1949. The manual on 'Psychological Operations in Guerrilla Warfare', whose publication and dissemination was the responsibility of the United States, advises certain acts which are to be regarded as contrary to that article. ${ }^{1098}$

Liberating himself from the actual reach of the judgement, Marx claims that Common Article 3 not only obliges parties to the conflict, but also 'any conceivable bearer of responsibility under international law' to refrain from immediate and mediated violations of its basic rights. ${ }^{1099}$ If

\footnotetext{
1097 Nicaragua Case, para. 219.

1098 Nicaragua Case, paras 219 and 292.

1099 'Diese Schutznorm kommt aber nicht erst bei der Unterstützung eines Konfliktbeteiligten zur Anwendung. Vielmehr will sie die unbeteiligte Zivilbevölkerung vor jeder unmittelbaren und mittelbaren Verletzung ihrer grundlegenden Rechte durch jeden denkbaren Träger völkerrechtlicher Verpflichtungen schützen.' Marx, 1996, p. 300.
} 
this were the case, Common Article 3 would possess a given place in the emerging refugee law of the EU. All Member States and first wave candidate countries have ratified the 1949 Geneva Conventions and are bound by Common Article $3^{1100}$; besides, its content would also be binding on them as part of the general principles of humanitarian law. ${ }^{1101}$ However, taking account of its greater transparency, the treaty obligation shall be looked into in the subsequent discussion.

Marx's line of argument is not convincing, as it runs counter to the very terms of Common Article 3. It emanates from the first sentence of Common Article 3 that this provision merely obliges states party to the conflict, and so do the general principles of humanitarian law alluded to by the Court. ${ }^{1102}$ To be sure, reading a prohibition of refoulement by states not parties to the conflict into Common Article 3 would amount to an interpretation contra legem. ${ }^{1103}$ The methodology of interpretation enshrined in the Vienna Convention and expounded at some length below ${ }^{1104}$ does not permit us to pursue an interpretative operation further when clarity has been attained by studying the ordinary meaning of the terms of the provision in question. ${ }^{105}$ And the ordinary meaning of the terms used in Common Article 3 entail its non-applicability to others than parties to the conflict.

The Nicaragua Case does not support Marx's argument either. The Court's conclusion was explicitly reached on the premise that the United States was party to an international armed conflict. ${ }^{1106}$ Thus, the Court did not expand the personal scope of Common Article 3 or its counterpart among the general principles of humanitarian law. Neither is it

1100 Source: IHL Database, available at < http://www.icrc.org/ihl > (accessed on 24 April 0).

1101 In some domestic legal orders, this offers the advantage of direct applicability.

1102 In the Nicaragua Case, there is no indication whatsoever that the Court considers the general principles of humanitarian law consuming the content of Common Article 3 to apply to non-parties to the conflict as well.

1103 This argument also strikes against Kjærum's support for a prohibition of refoulement implied in Common Article 3, which he bases partly on the provisions on the prosecution of war criminals, partly on an analogy to the case law under Article 3 ECHR. Kjærum, 1999, p. 285. These analogies can hardly alter the wording of Common Article 3. Therefore, together with the one taken by Marx, his position is untenable.

1104 See chapter 9.3 below.

1105 See Article 31 (4) VTC and text accompanying note 1121 below.

1106 Nicaragua Case, para. 219. 


\section{CHAPTER 9}

conceivable that a prohibition of refoulement would flow from other general principles of humanitarian law, as the personal scope of those is restricted to parties to the conflict. ${ }^{1107}$

Contrary to Marx's claim, the personal scope of Common Article 3 does not comprise all conceivable subjects of international law. The implicit prohibition of refoulement inherent in Common Article 3 would only oblige a host state which is party to the conflict.

This reduces the practical relevance of such a prohibition to a great extent. Properly speaking, it would offer protection to internally displaced persons. However, given that internally displaced persons per definition fail to have crossed an international boundary, this category falls outside the scope of the present work. Therefore, Common Article 3 shall not be included in the normative base. Nonetheless, the idea behind Marx's approach remains useful and merits further scrutiny.

We would propose another approach that offers the advantage of greater applicability in practice. We shall seek to expound whether norms of humanitarian treaty law applicable in international conflicts contain implicit prohibitions of refoulement.

The Fourth Convention contains a catalogue of rights in Part III, Section I, which protected persons are entitled to in the territories of the parties to the conflict as well as in occupied territories. This catalogue hosts inter alia the explicit prohibition of refoulement in Article 45 FC, already dealt with above. Here, we shall scrutinise Article $32 \mathrm{FC}$, obliging the parties to respect the life and physical integrity of protected persons:

The High Contracting Parties specifically agree that each of them is prohibited from taking any measure of such a character as to cause the physical suffering or extermination of protected persons in their hands. This prohibition applies not only to murder, torture, corporal punishments, mutilation and medical or scientific experiments not necessitated by the medical treatment of a protected person, but also to any other measures of brutality whether applied by civilian or military agents.

1107 Compare the allusion to 'obligations which the Parties to the conflict shall remain bound to fulfil by virtue of the principles of the law of nations, as they result from the usages established among civilized people, from the laws of humanity and the dictates of public conscience' in Convention I, Art. 63, Convention II, Art. 62, Convention III, Art. 142, Convention IV, Art. 158 (emphasis added). 
Precisely as in Article 3 ECHR and Article 7 ICCPR, this article might host an implicit prohibition of refoulement. With due regard to Article 4 $\mathrm{FC}$, a protection seeker is a protected person in the hand of a contracting party. Her return by the latter to a conflict zone could very well constitute a 'measure of such a character as to cause the physical suffering or extermination' of the said person. Considering the threat facing the returnee, the forcible implementation of return by civilian or military agents of the returning state could constitute a 'measure of brutality' in the sense of the second sentence.

If Article $32 \mathrm{FC}$ indeed hosts an implicit prohibition of refoulement, its scope of application is comparably narrow. Due to political reasons, a party to the conflict might not even wish to return persons potentially coming under its protection. Moreover, it would overlap to a certain extent with other explicit and implicit prohibitions of refoulement. Nonetheless, there is a theoretical interest in clarifying the matter, and it cannot be excluded that a protection seeker would find herself outside all conceivable protection categories, were it not for Article 32 FC. Therefore, it is reasonable to include this provision in the normative base underlying the ensuing inquiry.

\subsection{Access to Territory}

Which norms are prima facie relevant for answering the second question regarding access to protection? First, it must be recalled that the explicit and implicit prohibitions of refoulement dealt with above need to be reexamined in the light of the second question. After all, a state obligation to protect could embrace an obligation to allow access as well. Second, those norms of international human rights law which deal specifically with migration also need to be included in the normative base. Both the ICCPR and a Protocol to the ECHR contain pertinent articles that shall be presented in detail below.

\subsubsection{The ICCPR}

Article 12 (2), (3) and (4) ICCPR deals with the transgression of state borders. More specifically, it enshrines a carefully delimited right to international freedom of movement: 


\section{CHAPTER 9}

2. Everyone shall be free to leave any country, including his own.

3. The above-mentioned rights shall not be subject to any restrictions except those which are provided by law, are necessary to protect national security, public order (ordre public), public health or morals or the rights and freedoms of others, and are consistent with the other rights recognized in the present Covenant.

4. No one shall be arbitrarily deprived of the right to enter his own country.

To be precise, this provision contains two rights: entitlement to emigration from any country, including one's own, and entitlement to entry into one's own country. On a matter-of-fact basis, it can be stated that Article 12 is asymmetrical in that the right to emigrate is wider than the right to immigrate. Neither this provision, nor any other contained in the ICCPR, makes mention of a right to immigrate into states which are not one's 'own country'. Compared to its predecessors in the UDHR ${ }^{1108}$, Article 12 ICCPR specifies the conditions for restricting the right to leave, and qualifies the right to enter one's own country by prohibiting arbitrary deprivation.

\subsubsection{The Fourth Protocol to the ECHR}

Moving from the ICCPR to the regional system of human rights protection in Europe, we find that the right to leave and the right to entry are similarly framed. The 1963 Fourth Protocol to the ECHR ${ }^{1109}$ provides for both rights under the European system. While Article 2 (2) lays down a right to leave which is identically worded to the corresponding right in Article 12 (2) ICCPR, the clause on restrictions in Article 2 (3) of the Fourth Protocol is worded in a slightly different manner:

1108 Article 13 (2) UDHR is worded as follows: 'Everyone has the right to leave any country, including his own, and to return to his country'. This provision is subject to the limitations in Arts 29 and 30 UDHR.

1109 Protocol No. 4 to the European Convention for the Protection of Human Rights and Fundamental Freedoms, securing certain Rights and Freedoms other than those already included in the Convention and in the First Protocol thereto, Strasbourg, 16 September 1963, ETS No. 46 [hereinafter the Fourth Protocol]. 
2. Everyone shall be free to leave any country, including his own.

3. No restrictions shall be placed on the exercise of these rights other than such as are in accordance with law and are necessary in a democratic society in the interests of national security or public safety, for the maintenance of "ordre public", for the prevention of crime, for the protection of health or morals, or for the protection of the rights and freedoms of others.

Compared to Article 12 (4) ICCPR, the right to entry is moulded into more specific terms in the Fourth Protocol. Its Article 3 (4) explicitly limits this right to nationals:

No one shall be deprived of the right to enter the territory of the State of which he is a national.

However, its protective ambit is not limited to the arbitrary deprivation of the right to entry, but to any such deprivation. In this regard, the Fourth Protocol is more favourable than the ICCPR.

With the exception of Spain and the United Kingdom, all EU Member States have ratified the Fourth Protocol. It is regarded as part of the acquis, and the Council has classified it as an instrument which 'States applying to join the European Union should endeavour to become party of' ${ }^{1110}$ Already now, all first wave candidate countries are bound by the Fourth Protocol. Individuals can seize the European Court of Human Rights with complaints against those states that are parties to it. ${ }^{1111}$

\subsection{Methodology of Interpretation}

In the next move, it has to be clarified which norms of interpretation shall be used in establishing the precise content of the provisions singled out above. Articles 31-3 of the 1969 Vienna Convention on the Law of Treaties $^{1112}$ provide for the interpretation of treaties, which is at stake here. There is no doubt that the Vienna Convention, according to its Article 4, is not to be applied retroactively. This bars direct recourse to its

\footnotetext{
1110 Draft List, para. XII. D.

1111 See Art. 34 of the $11^{\text {th }}$ Protocol to the ECHR.

1112 Vienna Convention on the Law of Treaties, 24 May 1969, 1155 UNTS 331.
} 


\section{CHAPTER 9}

interpretative norms when grappling with the 1949 Fourth Convention, the 1950 ECHR, its 1963 Fourth Protocol, the 1951 Refugee Convention, the 1966 ICCPR and the 1966 First Protocol. However, it is widely agreed that Articles 31-3 VTC are reflective of customary international law on the interpretation of treaties, valid at least throughout the post-war period at stake here. ${ }^{1113}$ As an example, the Human Rights Committee has explicitly referred to the Vienna Convention when interpreting the $\mathrm{ICCPR}^{1114}$, and so did the ECtHR when construing the ECHR ${ }^{1115}$. Even the ICJ has confirmed that the principles in Articles 31 and 32 VTC reflect customary international law. ${ }^{1116}$ For practical reasons, we shall refer to Articles 31-3 VTC even when interpreting instruments concluded before its entry into force. Such references shall be understood as alluding to the corresponding norms in customary international law.

It should be underscored that the rules on interpretation contained in Articles 31-3 VTC are binding treaty law for the parties. ${ }^{1117}$ The vast majority of Member States and first wave candidate countries have ratified this instrument. ${ }^{118}$ Those who have not are bound to apply identical rules of customary international law. ${ }^{1119}$ Accordingly, neither Member States nor first wave candidate countries can choose freely which standards to apply to the interpretation of their international treaty obligations; rather, they are duty-bound to revert to the content of Articles 31-3 VTC.

Article 31 VTC provides for a 'General Rule of Interpretation'. Its first paragraph merits quoting in full:

A treaty shall be interpreted in good faith in accordance with the ordinary meaning to be given to the terms of the treaty in their context and in the light of its object and purpose.

\footnotetext{
1113 I. Sinclair, The Vienna Convention on the Law of Treaties (1984, Manchester University Press, Manchester), pp. 19 and 153.

1114 Human Rights Committee, Alberta Union v. Canada, B118/1982, para. 6.3.

1115 ECtHR, Golder Case, 21 February 1975, Vol. A 18, p. 14.

1116 ICJ, Case Concerning the Arbitral Award of July 21, 1989, Judgment of 12 November 1991, ICJ Reports 1991, p. 53, at pp. 69-72.

1117 For an exploration on the bindingness of rules of interpretation, see Bernhardt, 1992, p. 1418.

1118 Save for France, Ireland and Portugal, all Member States are bound by the VTC. Among first wave candidate countries, only Malta is not bound by the VTC. Ratification data as of 28 June 1999, contained in UNHCR Refworld database, July 1999 edition.

1119 Bernhardt, 1992, p. 1418.
} 
Article 32 VTC deals with supplementary means of interpretation and their use, while Article 33 VTC spells out rules for the interpretation of treaties authenticated in two or more languages.

But Articles 31 and 32 VTC are not merely instructing international lawyers where to look for raw material informing their interpretation, but also in what order and under which conditions to use such material. Based on a systematic analysis of both provisions, Linderfalk has identified a hierarchical methodology of interpretative operations. ${ }^{1120}$ The methodology inherent in the named standards stretches over a maximum of three stages. In the first stage, the interpreter shall establish the ordinary meaning to be given to the terms of a treaty. Where this operation leads to a clear result, interpretation has come to an end, and no further action is necessary. ${ }^{1121}$ If and only if such clarity is not attained, the interpreter shall proceed to the second stage, drawing on the context as well as the object and purpose of the treaty to dissolve the ambiguity resting in the 'ordinary meaning'. ${ }^{1122}$ Where the content of a provision is clarified in the second stage, interpretation has come to an end. If and only if such clarity is not attained, the interpreter shall proceed to a third stage, taking recourse to supplementary means of interpretation along the provisions of Article 32 VTC. ${ }^{1123}$ Among other data, the third stage makes the travaux available to the interpreter.

It is quite obvious that the notion of clarity plays a prominent role in the correct application of Articles 31 and 32 VTC. Stating that the matter is clear may stop interpretation from proceeding to a subsequent stage, and thus bar additional data from being admitted to the interpretative process. Stating that the outcome of interpretation is still ambiguous

${ }^{1120}$ U. Linderfalk, Om tolkning av traktater (2000, unpublished dissertation manuscript, on file with the author).

1121 Compare Art. 31 (4) VTC, shifting the burden of proof to those who argue for an interpretation beyond 'the ordinary meaning' of the terms of the treaty. M. K. Yasseen, 'L'interprétation des traités d'après la Convention de Vienne sur le droit des traités', Recenil des Cours 151[III] (1976), p. 28. This is precisely where the border between the first and the second step is located.

1122 For an express confirmation of this step-by-step method, see ICJ, Case Concerning the Arbitral Award of July 21, 1989, Judgment of 12 November 1991, ICJ Reports 1991, p. 53 , at pp. 69-72, summarising some of its earlier dicta on interpretation.

${ }^{1123}$ Yasseen, 1976, pp. 78-82, underscoring that recourse to the supplementary means of interpretation is to be considered as a distinct step in the interpretative operation. See also YILC 1966, II, p. 219. However, it should be noted that Art. 32 VTC may also be used to confirm the result of an interpretative operation under the first two stages. 


\section{CHAPTER 9}

opens the gates to further evidence of meaning and intent, evidence that may give interpretation a wholly new direction. The Vienna Convention does not define clarity, which leaves the international lawyer with a subjective margin.

Mindful of the order prescribed by the VTC, we shall now identify norms for which the 'ordinary meaning to be given to the terms of the treaty' is not enough to establish the content of state obligations vis-à-vis protection seekers. Going through those parts of the normative base singled out as binding above, we shall identify a group of hard cases, which will be taken to the second and, where necessary, even the third stage in chapter 10 .

\subsection{Identifying Hard Cases}

In the following, it shall be established whether the questions on protection and access can be answered by interpreting the ordinary meaning to be given to the terms of the treaty norms in question.

\subsubsection{Protection: Implicit Prohibitions of Refoulement}

The first question was whether EU Member States are under an obligation to grant extraterritorial protection.

All of the express prohibitions of refoulement scrutinised above are unproblematic. The wording of Article $33 \mathrm{GC}$, of Article $3 \mathrm{CAT}$ and of Article 45 FC, respectively, establish that EU Member States are under an obligation to refrain from refoulement. While the precise scope of these obligations is in need of further clarification ${ }^{1124}$, their content is sufficiently clear to answer the question quoted above: Member States are under a legal obligation to grant extraterritorial protection. In this respect, there is no need to proceed to further stages in the interpretative operation.

Different is the case of implicit prohibitions of refoulement in human rights law and humanitarian law. The question whether and to what

\footnotetext{
${ }^{1124}$ Among other things, the precise personal scope of these prohibitions is not clear (see inter alia chapter 12.2.2 below).
} 
extent these norms entail an obligation to grant extraterritorial protection has yet to be answered.

\subsubsection{Article 3 ECHR and Article 7 ICCPR}

The wording of Article 3 ECHR and Article 7 ICCPR is not of much help when it comes to the issue of extraterritorial protection. The sole insight to be derived from it is the fact that no one shall be subjected to certain forms of ill-treatment.

The ambiguity of interpretation emerged clearly in Soering, the first landmark case on Article 3 ECHR before the European Court of Human Rights. ${ }^{1125}$ Although Soering concerned extradition, it unlocked the protective potential of Article $3 \mathrm{ECHR}$ for asylum as well. ${ }^{1126}$ The issue to be decided was whether it was permissible for the U.K. to extradite a suspected murderer to the United States of America, where he faced the risk of capital punishment and placement in a specific prison wing, commonly known as 'death row'. The responding U.K. government claimed that 'it would be straining the language of Article 3 [...] intolerably to hold that by surrendering a fugitive criminal the extraditing State has "subjected" him to any treatment or punishment that he will receive following conviction and sentence in the receiving State' ${ }^{1127}$ This view was not shared by the Court, which apparently regarded the language of Article 3 as ambiguous. Rather, it based the applicability of that provision in extradition cases on contextual and teleological arguments. ${ }^{1128}$ Accepting the counsel's claim that the conditions in death row indeed were inhuman, the Court concluded that extradition by the U.K. would violate Article 3 ECHR. ${ }^{1129}$ The U.K. government, however, remained unconvinced. When the Chabal case ${ }^{1130}$ came before the Commission, the Government underscored 'that, contrary to the view of

\footnotetext{
1125 ECtHR, Soering vs. the U.K., Series A, No. 161 [henceforth Soering].

1126 In Cruz Varas, the Court held that Art. 3 was applicable not only to extradition cases, but a fortiori also to expulsion cases. ECtHR, Cruz Varas ws. Sweden, Series A, No. 201 [henceforth Cruz Varas], para. 69.

1127 Soering, para 83.

1128 See chapter 10.1.1.1 below on the second stage of interpretation.

1129 Thus, in the Court's opinion, it was neither the risk of capital punishment nor that of execution, which would have made extradition a violation of the ECHR.

1130 See text accompanying note 180 above.
} 


\section{CHAPTER 9}

the Court in the Soering and Vilvarajah cases, Article 3 [...] of the Convention has no extra-territorial effect, but should be construed as a prohibition on a Member State exposing persons within its own jurisdiction to torture or to inhuman or degrading treatment'. ${ }^{1131}$

Tracking down the ordinary meaning of 'to subject' and 'a soumettre' respectively ${ }^{1132}$ does not solve the problem. The former means 'to cause to undergo or experience some action or treatment ${ }^{3133}$, while the latter

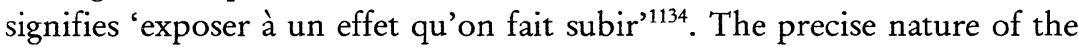
causality alluded to in these explanations can hardly be established by resorting to a semantic, grammatical and pragmatic analysis, however.

To wit, the terms of Article 3 ECHR and Article 7 ICCPR fail to answer in a sufficiently clear manner whether removal to ill-treatment in a third country is covered or not. A line of reasoning built on the assumption that the removal from one country and the anticipated human rights violation in the destination country are to be seen as non-divisible will lead to an affirmative position. On the other hand, perceiving the act of removal and the act of violating human rights as two separate phenomena typically supports a denial of non-refoulement obligations inherent in both provisions. True enough, Article $3 \mathrm{ECHR}$ and Article 7 ICCPR enshrine certain rights to the benefit of individuals, but it is unclear whether these entail state obligations to grant extraterritorial protection. Only by moving on to the second stage of the interpretative operation can clarity be attained.

\subsubsection{Article 32 FC}

Precisely as in the case of Article 3 ECHR and Article 7 ICCPR, the issue of causality is critical for a proper interpretation of Article $32 \mathrm{FC}$. The ordinary meaning of the phrase 'taking any measure of such a character as to cause' is open to conflicting interpretations on whether such causation

${ }^{1131}$ European Commission of Human Rights, Application No. 22414/93, The Chabal Family against the United Kingdom, Report of the Commission (adopted on 27 June 1995), para. 92.

1132 The English and French texts of the ECHR are equally authentic.

1133 Websters New World Dictionary of the American Language (1970, The World Publishing Company, New York and Cleveland), p. 1418.

1134 Le Mirco-Robert (1988, Dictionnaires le Robert, Paris). 
must be direct or may also be indirect. A proper reading of the terms of Article $32 \mathrm{FC}$ reveals that it only covers direct causation.

The nexus between the first and the second sentence of Article $32 \mathrm{FC}$ is of particular relevance in this context. Let us have a second look at the wording of the provision:

The High Contracting Parties specifically agree that each of them is prohibited from taking any measure of such a character as to cause the physical suffering or extermination of protected persons in their hands. This prohibition applies not only to murder, torture, corporal punishments, mutilation and medical or scientific experiments not necessitated by the medical treatment of a protected person, but also to any other measures of brutality whether applied by civilian or military agents.

In the first sentence, measures causing the physical suffering or extermination of persons in the hands of a Contracting Party are prohibited. In the second sentence, the prohibited measures are exemplified. Murder, torture and the other measures explicitly named have in common that they constitute violations of the physical integrity of the protected person. In line with the interpretative principle of ejusdem generis ${ }^{1135}$, the phrase 'any other measure of brutality' must be understood to share this characteristic. This suggests that the drafters did not wish to include the indirect causation of physical suffering or extermination in the protective scope of this provision. Otherwise, they could have easily omitted the words 'of brutality' or extended the list of examples with an explicit reference to removal situations. Therefore, Article $32 \mathrm{FC}$ does not contain an implicit prohibition of refoulement. By consequence, this provision can also be discarded from our scrutiny of the question of access to territory.

1135 See note 1047 above. The first stage of interpretation-i.e. the identification of the 'ordinary meaning' of the terms of a treaty-covers not only a lexical, but also a grammatical and pragmatic study. Ejusdem generis is all about the pragmatics of legal language. 


\section{CHAPTER 9}

\subsubsection{Access to Territory}

The second question was whether an individual entitlement to migrate in order to seek such protection exists. Migration is a composite of leaving one country and entering another. Therefore, the right to leave as well as the right to entry has to be scrutinised. Given the ever more widespread usage of control mechanisms outside state territory (e.g. pre-entry measures such as carrier sanctions combined with visa requirements), our examination of the right to entry can be further differentiated. The regulation of entry at the border of a potential host state should be dealt with separately from the regulation of entry by means of externalised control mechanisms. In the former case, it can be argued that the claimant has made contact with state territory, which usually results in a more advantageous legal position. The same is not true for a claimant visiting the embassy of a potential host country in her home country, asking for an entry visa. ${ }^{1136}$ Here, the absence of territorial contact might impact negatively on the claimant's legal position. In the following, we shall deal with both access situations, looking into the impact of relevant provisions on access at the border and access from outside the potential host state.

\subsubsection{The Right to Leave and the Right to Entry}

With regard to emigration, the matter is clear. It emanates from the wording of Article 12 (2) and (3) ICCPR and from Article 2 (2) and (3) of the Fourth Protocol that everyone has a right to leave any country, including his own, albeit this right is subject to certain limitations. As clarity has been attained in the first stage, recourse to contextual or teleological interpretation is unnecessary.

The other side of the coin, that is, immigration, entails greater difficulties. As earlier noted, neither of the provisions in the normative base contains a reference to immigration, be it in the permissive or in the limitative sense. A universalist would conclude that a right to immigrate is a necessary corollary of the right to emigrate. Admitting the right to emigration while denying a right to immigration would be a contradiction in terms. A particularist would disagree with this notion and underscore

${ }^{1136}$ It should be underscored that, legally and practically, this case is different from one where diplomatic asylum is sought. 
that the ICCPR represents an enumeration of rights: the wording of its provisions demarcates the reach of the entitlements contained in them. A right can not simply be deduced from the silence of the text. If the texts are silent with regard to the right to immigration it is because their drafters did not want such a right to exist. Both positions exceed the wording of the said norms and draw on a deeper conflict: whether, in case of conflict, to give prevalence to the logic of the law or the will of its drafters.

To conclude, clarity cannot be attained on the right to entry by recourse to the terms of the said treaty provisions. It is thus indispensable to involve their context and telos.

\subsubsection{Explicit Prohibitions of Refoulement}

A prohibition of refoulement may be merely taken as a state obligation not to remove a certain group of persons present on its territory to the country of persecution. However, the question is whether such prohibitions shall be interpreted as implying an additional obligation. The question is whether states are bound to admit persons applying for protection at the state border or from outside state territory. While nonremoval entails a right to transgress an administrative border (namely to be admitted to the state community, although in a minimalist sense), nonrejection would entail a right to transgress a physical border as well. If non-rejection is a legal corollary of the prohibition of refoulement, Article 33 GC, Article 3 CAT and Article 45 FC would contain an implicit right to entry for their beneficiaries.

It is clear, though, that the wording of all three provisions does not allow for deducing a right to entry in the absence of territorial contact with the potential host state. In other words, a person demanding an entry visa at the embassy of a Contracting Party cannot invoke the said norms. In such cases, one cannot speak of expulsion, return, refoulement or transfer 'to the frontier of territories' ${ }^{\text {'1137 }}$ or 'to another State ${ }^{1138}$ or 'to a country ${ }^{\prime 139}$ from which the specified threats originate.

\footnotetext{
1137 Art. 33 GC.

1138 Art. 3 CAT.

1139 Art. 45 FC.
} 


\section{CHAPTER 9}

The ambiguity of all the above provisions is limited to cases where a person presents herself at the border of the territory of a Contracting Party. An inclusive reading would be based on the understanding that such a person has already left the territory from which a pertinent threat emanates. Therefore, denying entry to the territory of the Contracting Party would constitute return 'to the frontiers of' such territories or 'to another State' or transfer 'to a country' hosting the specific threat. An exclusive reading would propose that a person who is present at the border has neither left nor entered a territory. Therefore, it would be wrong to call the denial of entry a form of return. Since Article $33 \mathrm{GC}$, Article $3 \mathrm{CAT}$ and Article $45 \mathrm{FC}$ only have a bearing on return, such a person would fall outside their protective scope.

With regard to rejection at the border, we note that the terminological couplet 'return ("refouler")' is used in both Article 33 GC and Article 3 CAT. This exposes a literal interpretation to a problematic tension. The ordinary meaning of the English term 'return' normally excludes rejection at the border ${ }^{1140}$, while the French term 'refouler' precisely includes such rejection. ${ }^{1141}$ In short, this is not a case where the interpretative rule of Article 33 (4) VTC-dealing with divergences of meaning between the authentic language versions of one and the same treaty text-applies. ${ }^{1142} \mathrm{In}$ the present case, the divergence of meaning stems from one and the same language version, namely the English one, which happens to feature a French term.

The linkage between the English and the French term is not easily understood. If the drafters had perceived both terms as congruent, why was it necessary to add the French term to the English version of the text? If the drafters were conscious of the difference in meaning, why did they

${ }^{1140}$ Following Webster's, the most appropriate connotation in the present context would be 'to bring, send, or put back to a former or proper place'. Webster's New World Dictionary of the American Language, 1970.

${ }^{1141}$ Davy refers to the following explanation given in the Grand dictionnaire Larousse VIII: 'Refouler qqn, un groupe [...] les repousser, les faire reculer par la force ou les empêcher de passer qqpart, de pénétrer dans un lieu et notamment dans un pays; chasser [...] Refouler des immigrants à la frontière'. U. Davy, Asyl und internationales Flücbtlingrecht, Band I: Völkerrechtlicher Rahmen (1996, Verlag Österreich, Wien), p. 104, note 55.

1142 Art. 33 (4) VTC reads: 'Except where a particular text prevails in accordance with paragraph 1, when a comparison of the authentic texts discloses a difference of meaning which the application of articles 31 and 32 does not remove, the meaning which best reconciles the texts, having regard to the object and purpose of the treaty, shall be adopted'. 
refrain from clarifying matters in the English language, e.g. by expressly including rejection at the border among the listing of prohibited acts?

Instead of 'return' or 'refouler', the Fourth Convention uses the verb 'to transfer'. This term denotes 'to convey from one person, place, or situation to another'. ${ }^{1143}$ A person rejected at the border of a certain state is actually moved over from the jurisdiction of this state to that of another one. Therefore, it could be argued that the prohibition of transfer includes rejection at the border. On the other hand, the term is less precise than refoulement, and the practice of rejection lies at the fringes of its ordinary meaning.

Regarding all of the three named instruments, the mere wording of the provisions does not allow for a clear-cut interpretation. Therefore, it is indispensable to move to the second stage.

\subsubsection{Implicit Right to Access}

In addition to the scrutiny of explicit prohibitions of refoulement, it may be asked whether Article 3 ECHR, Article 7 ICCPR and Article 32 FC protect a claimant not only inside the territory, but also at the borders of a Contracting State. Apart from border situations, it needs to be assessed whether both provisions apply to persons neither within the territory nor at the border of a potential host state. In contrast to both Article 3 CAT and Article 33 GC, nothing in the wording of Article 3 ECHR, Article 7 ICCPR and Article $32 \mathrm{FC}$ precludes that they protect persons attempting to avert the risk of ill-treatment by demanding admission at the border, or an entry visa at the embassy of a Contracting Party. If one concedes that the latter provisions indeed represent an individual entitlement to extraterritorial protection, it is fully arguable that they imply a right to entry as well. The very fact that such a right needs to be derived from the wording of the said provisions makes it contestable, however. A particularist interpreter would claim that the silence of the ECHR, the ICCPR and the FC with regard to refoulement is proof enough that their provisions were never intended to give rise to extraterritorial effects. The universalist interpreter would argue the opposite, pointing to the fact that a broad interpretation maximises the protection with which both instruments are tasked. Both a universalist and a particularist

1143 Websters New World Dictionary of the American Language, 1970. 


\section{CHAPTER 9}

interpretation go beyond the terms of Article $3 \mathrm{ECHR}$, Article 7 ICCPR and Article 32 FC. Therefore, the double ambiguity of these provisions with regard to the right to entry cannot be solved in the first stage of the interpretative operation.

\subsubsection{Interim Conclusion on the First Stage}

In all, focusing on the 'ordinary meaning of the terms' of relevant provisions contained in the normative base did not yield full clarity. Regarding the issue of protection, it could be clarified that Article 33 GC, Article $3 \mathrm{CAT}$ and Article $45 \mathrm{FC}$ oblige states to refrain from refoulement. Nonetheless, it remains unclear whether Article 3 ECHR, Article 7 ICCPR and Article 32 FC cover situations where the threat of violation is situated outside the territory of a potential host state.

Regarding the issue of access, it could be clarified that international law endows the individual with a right to leave. It could not be established whether the silence on a corresponding right to entry shall be construed in a permissive or a prohibitive manner. This ambiguity is reflected in the interpretation of Article $33 \mathrm{GC}$, Article $3 \mathrm{CAT}$, Article $3 \mathrm{ECHR}$, Article 7 ICCPR and Articles 32 and 45 FC. It is fully possible to argue-and to contest-that the wording of these provisions allows for deriving punctual rights to access. However, an analysis of the terms of Article $33 \mathrm{GC}$, Article 3 CAT and Article 45 FC could exclude their applicability outside the territory and beyond the border area of a potential host state.

For ease of understanding, the effect of the claimant's location on the applicability of these norms is displayed in Table 6 below. Evidently, the entry 'arguable' dominates at this stage of reasoning; this illustrates the ambiguity of the 'ordinary meaning' of the terms used in the norms scrutinised here. 


\begin{tabular}{llll}
\hline & $\begin{array}{l}\text { Claimant is } \\
\text { situated within } \\
\text { the territory of } \\
\text { a potential host } \\
\text { state }\end{array}$ & $\begin{array}{l}\text { Claimant is } \\
\text { situated at the } \\
\text { border of a } \\
\text { potential host } \\
\text { state }\end{array}$ & $\begin{array}{l}\text { Claimant is } \\
\text { situated } \\
\text { elsewhere }\end{array}$ \\
\hline Art. 33 GC & Yes & Arguable & No \\
Art. 3 CAT & Yes & Arguable & No \\
Art. 45 FC & Yes & Arguable & No \\
Art. 3 ECHR & Arguable & Arguable & Arguable \\
Art. 7 ICCPR & Arguable & Arguable & Arguable \\
Art. 32 FC & No & No & No \\
\hline
\end{tabular}

Table 6: Applicability ratione loci of Selected Norms in Relation to a Potential Host State. Results of the First Stage. 